Konrad Składowski

Katedra Prawa Konstytucyjnego

Uniwersytet Łódzki

\title{
ROZPORZĄDZENIE Z MOCĄ USTAWY W KONSTYTUCJI RZECZYPOSPOLITEJ POLSKIEJ Z 2 KWIETNIA 1997 R. UWAGI KRYTYCZNE
}

Rozporządzenie z mocą ustawy jest formą aktu normatywnego, która w polskiej tradycji konstytucyjno-prawnej ma długą historię, choć konkretne rozwiązania dalece różniły się między sobą ${ }^{1}$. Różną też stosowano w Polsce terminologię na określenie tej formy aktu. Polskie Konstytucje posługiwały się nazwami: rozporządzenie z mocą ustawy lub dekret z mocą ustawy. Oba te terminy stosowane są $\mathrm{w}$ polskim prawodawstwie konstytucyjnym zamiennie, choć w literaturze przedmiotu zwraca się uwagę na to, że nazwa dekret byłaby właściwsza².

W polskiej literaturze opisuje się je jako akt normatywny o zakresie przedmiotowym ustawy, wydawany przez inny organ niż parlament ${ }^{3}$. Tę czy inną formę ustawodawstwa delegowanego przewidywały wszystkie polskie dwudziestowieczne Konstytucje. Jedynie w dwóch okresach ta forma aktu normatywnego nie występowała w polskich regulacjach konstytucyjnych.

\footnotetext{
${ }^{1}$ Szerzej na ten temat zob.: B. Dzierżyński, Rozporządzenia z mocą ustawy jako akty nadzwyczajnego ustawodawstwa delegowanego na tle Konstytucji polskich - wybrane problemy, „Przegląd Prawa i Administracji”, Wrocław 2003, t. LIV, s. 65-80; M. Nowakowski, Ustawodawstwo delegowane w polskim prawie konstytucyjnym, „Przegląd Sejmowy” 2005, nr 3, s. 49-57; W. Skrzydło, Ustawodawstwo delegowane w polskim prawie konstytucyjnym, [w:] L. Garlicki, A. Szmyt (red.), Sześć lat Konstytucji Rzeczypospolitej Polskiej, doświadczenia i inspiracje, Warszawa 2003, s. 271-276.

${ }^{2}$ Zob. przypis 3 w: D. Górecki, 0 przydatności instytucji dekretu z mocq ustawy w polskim prawie konstytucyjnym, [w:] A. Pułło (red.), Zagadnienia współczesnego prawa konstytucyjnego, Gdańsk 1993, s. 119.

${ }^{3}$ K. Działocha, Dekret z moca ustawy w państwie burżuazyjnym, Wrocław 1964, s. 6; K. Eckhardt, Rozporządzenie z mocq ustawy, [w:] W. Skrzydło, S. Grabowska, R. Grabowski (red.), Konstytucja Rzeczypospolitej Polskiej, komentarz encyklopedyczny, Warszawa 2009, s. 510.
} 
Pierwszy to okres obowiązywania Konstytucji marcowej z 1921 r. do czasu uchwalenia noweli sierpniowej w 1926 r., przy czym w doktrynie formułowano pogląd, że prawo do ich wydawania można wyinterpretować z innego postanowienia Konstytucji ${ }^{4}$. Drugi nastąpił po nowelizacji Konstytucji z 1952 r., która miała miejsce w kwietniu 19895. Jednak już ustawa konstytucyjna z 17 października z 1992 „o wzajemnych stosunkach między władzą ustawodawczą i wykonawczą oraz o samorządzie terytorialnym" przywróciła tę formę aktu normatywnego ${ }^{6}$.

Uprawnienie do ustawodawstwa delegowanego wynikać może z upoważnienia Konstytucji lub ustawy. Oba te rozwiązania stosowane były w Polsce w przeszłości. Niekiedy równocześnie w tej samej Konstytucji. Jak zauważono w literaturze, rozporządzenia z mocą ustawy mogą być wydawane $\mathrm{w}$ „zakresie spraw regulowanych co do zasady w drodze ustaw, a więc w zakresie władzy ustawodawczej"'. Supremacja parlamentu w zakresie prawodawstwa powoduje, że funkcjonowanie ustawodawstwa delegowanego traktowane jest we współczesnych państwach demokratycznych jako ograniczenie władzy ustawodawczej, przez co stosowanie tej instytucji powinno być nader umiarkowane ${ }^{8}$. Niemniej od początku XX wieku można obserwować wzrost liczby i znaczenia aktów ustawodawstwa delegowanego jako konkurencyjnej w stosunku do ustaw formy tworzenia prawa. Czynniki, które miały na to wpływ, to z jednej strony coraz bardziej widoczna niewydolność ustawodawcza parlamentu, w szczególności obradującego w systemie sesyjnym, w stosunku do konieczności wynikających z dynamicznych przeobrażeń społeczno-ekonomicznych ${ }^{9}$, a z drugiej konieczność szybkiej reakcji prawodawczej państwa w razie nagłej konieczności państwowej spowodowanej przede wszystkim stanem zagrożenia państwa ${ }^{10}$.

Obserwując polskie doświadczenia, można uznać, że powodem wprowadzania tej formy aktów prawnych była również chęć zachowania zdolności prawodawczej państwa w sytuacji groźby kryzysu państwowości spowodowanej konfliktem zbrojnym. Taki charakter miały dekrety z mocą

${ }^{4}$ E. Zwierzchowski, Z zagadnień delegacji ustawodawczej Polski międzywojennej, „Zeszyty Naukowe Uniwersytetu Jagiellońskiego. Prace Prawnicze" 1963, z. 10, s. 96-111.

${ }^{5}$ Dz. U. Nr 19, poz. 101.

${ }^{6}$ Dz. U. Nr 84, poz. 426.

${ }^{7}$ K. Działocha, Rozporzq̨dzenia z mocq ustawy $w$ świetle ustawy konstytucyjnej z dnia 17 października 1992 roku, „Przegląd Sejmowy” 1993, nr 1, s. 50.

${ }^{8} \mathrm{R}$. Piotrowski, 0 potrzebie rozporzq̨dzeń z mocq ustawy $w$ polskim systemie tworzenia prawa, [w:] A. Bałaban, P. Mijał (red.), Zasady naczelne Konstytucji RP z 2 kwietnia 1997 roku, Szczecin 2011, s. 261-266.

${ }^{9}$ W. Skrzydło, dz. cyt., s. 271.

${ }^{10} \mathrm{~K}$. Prokop, O dopuszczalności oraz zakresie przedmiotowym rozporządzeń z mocq ustawy w czasie stanu wojennego, „Przegląd Sejmowy” 2002, nr 3, s. 47. 
ustawy przewidziane w Konstytucji kwietniowej z 1935 r., które uprawniały Prezydenta do ich wydawania w zakresie wszelkich kwestii z wyjątkiem zmiany Konstytucji. Z uprawnienia tego korzystali Prezydenci RP na uchodźstwie. Podobny cel miały również dekrety, które stosowane były w okresach 1918-1921 przez Tymczasowego Naczelnika Państwa oraz Radę Obrony Państwa, jak również w latach 1944-1947 przez Polski Komitet Wyzwolenia Narodowego, a potem Rząd Tymczasowy RP. W literaturze zwracano także uwagę, że rozporządzenia z mocą ustawy mogą służyć przezwyciężaniu niezdolności państwa do stanowienia prawa ze względu na stałą niewydolność Sejmu w sprawowaniu funkcji ustawodawczej, spowodowaną głęboką fragmentaryzacją polityczną parlamentu ${ }^{11}$.

Analiza obowiązującej regulacji konstytucyjnej jednoznacznie wskazuje, że instytucja rozporządzenia z mocą ustawy jest pomyślana jako instrument, który ma zapewniać zdolność prawotwórczą państwa w warunkach zagrożenia państwa. $\mathrm{Z}$ tego względu poza obszarem czynionych rozważań pozostawiam kwestię analizy ewentualnej potrzeby wyposażenia organów władzy wykonawczej w Polsce w prawo wydawania tych aktów w innych okolicznościach i tym samym rozszerzenia możliwości ich wydawania, co jest także przedmiotem refleksji w doktrynie prawa konstytucyjnego ${ }^{12}$.

$\mathrm{Na}$ marginesie warto wskazać na pewne rozbieżności w ocenie kategoryzacji „prawodawstwa wyjątkowego”. Część przedstawicieli doktryny podkreśla wyraźną różnicę między nimi a rozporządzeniami czy też dekretami wydawanymi poza czasem stanu szczególnego zagrożenia państwa. Dokonując niejako podziału dekretów na ustawodawstwo delegowane i nadzwyczajne ustawodawstwo delegowane, wskazuje się, że różnica tkwi w „odmiennych przesłankach prawnych uzasadniających działanie organów wykonawczych", tzn. wyjątkowej sytuacji wewnętrznej, w jakiej znajduje się państwo ${ }^{13}$. Choć trudno nie zgodzić się ze wskazanymi różnicami w genezie tych instytucji, to warto podkreślić, że taka sama moc prawna obu rodzajów ustawodawstwa delegowanego czyni je instytucjami zbliżonymi ${ }^{14}$.

Problematyka rozporządzeń z mocą ustawy w polskiej Konstytucji doczekała się już kilku interesujących opracowań ${ }^{15}$. Z tego względu w niniejszym tekście uwagę swą skoncentruję przede wszystkim na kwestiach bu-

${ }^{11}$ D. Górecki, dz. cyt., s. 118; B. Naleziński, K. Wojtyczek, Rozporządzenie z mocq ustawy w polskim systemie kontroli konstytucyjności prawa, „Przegląd Sejmowy” 1995, nr 3, s. 35.

${ }^{12}$ R. Piotrowski, dz. cyt. s. 280-284.

${ }^{13}$ K. Działocha, Dekrety..., s. 14; B. Dzierżyński, dz. cyt., s. 64-65.

${ }^{14}$ K. Prokop, Stany nadzwyczajne w Konstytucji Rzeczypospolitej Polskiej, Białystok 2005, s. 166.

${ }^{15}$ B. Dzierżyński, dz. cyt., s. 63-91; M. Nowakowski, Ustawodawstwo..., s. 47-64; K. Prokop, 0 dopuszczalności oraz zakresie..., s. 47-59; W. Skrzydło, dz. cyt., s. 270-284. 
dzących wątpliwości, mniej uwagi poświęcając zagadnieniom niebudzącym szczególnych kontrowersji. Poza obszarem rozważań pozostawiam także kwestie historii ustawodawstwa delegowanego w Polsce, jak również, o czym pisałem wcześniej, zagadnienia ustawodawstwa delegowanego niezwiązanego z wyjątkową sytuacją wewnętrzną państwa.

Zgodnie z art. 234 Konstytucji prawo wydawania rozporządzeń z mocą ustawy posiada Prezydent, na mocy delegacji konstytucyjnej bez konieczności uchwalenia ustawy upoważniającej. Należy jednak przy tym spełnić tyle warunków, że w zasadzie uprawnienia Prezydenta w zakresie ustawodawstwa delegowanego zostały w obowiązującej Konstytucji ograniczone do minimum.

Rozporządzenie z mocą ustawy może być wydane przez Prezydenta przy spełnieniu łącznie kilku przesłanek. Pierwszą z nich jest ogłoszenie stanu wojennego, drugą niemożność zebrania się Sejmu na posiedzenie, trzecią natomiast złożenie stosownego wniosku przez Radę Ministrów.

Wydawanie tych aktów jest dopuszczalne wyłącznie w czasie stanu wojennego, który stanowi jeden z trzech stanów nadzwyczajnych przewidzianych w Konstytucji. Dzień wejścia w życie rozporządzenia Prezydenta o wprowadzeniu stanu wojennego w trybie art. 229 Konstytucji na części albo na całym terytorium państwa jest momentem, od którego nabywa on możliwość korzystania z tej formy tworzenia prawa. Jednocześnie wprowadzenie stanu wojny bez zarządzenia stanu wojennego nie uprawnia Prezydenta do ich wydawania.

Przesłanka ta wskazuje, że wydawanie rozporządzeń traktowane jest jako zdarzenie przewidziane dla nadzwyczajnych okoliczności. Można znaleźć uzasadnienie dla tego typu konstrukcji prawnej, aczkolwiek niespójne wydaje się uznanie przez prawodawcę konstytucyjnego, że jedynie w stanie wojennym może mieć miejsce sytuacja sprawiająca, że wydawanie rozporządzeń z mocą ustawy staje się konieczne. Można wyobrazić sobie okoliczności powodujące, że również w stanie wyjątkowym może zachodzić potrzeba ich wydawania. Tymczasem $\mathrm{w}$ razie niezdolności parlamentu do działania w czasie stanu wyjątkowego państwo pozostaje bez możliwości tworzenia aktów o randze ustawowej. Dodatkowe ograniczenia w zakresie wydawania rozporządzeń z mocą ustawy zawarte w Konstytucji powodują, że rozszerzenie tego prawa na stan wyjątkowy nie rodzi obaw co do ewentualnej możliwości ich nadużywania przez organy władzy wykonawczej. Stąd wydaje się, że postulat przyznania Prezydentowi prawa do ich wydawania również $\mathrm{w}$ stanie wyjątkowym nie stoi w sprzeczności z uprzywilejowaną pozycją parlamentu w zakresie prawodawstwa.

Drugą przesłanką jest niemożność zebrania się Sejmu na posiedzenie. Chodzi w tym przypadku o fizyczną niezdolność Sejmu do działania, a nie 
niezdolność do pełnienia funkcji ustawodawczej Sejmu spowodowaną jego fragmentaryzacją polityczną. Sformułowanie zawarte w art. 234 Konstytucji w zgodnych poglądach doktryny oznacza niemożność sprawowania przez Sejm funkcji ustawodawczej ${ }^{16}$. Oznacza to, że dla podejmowania uchwał przez Sejm konieczne jest osiągnięcie kworum, które wynosi połowę ustawowej liczby posłów, czyli 230. Konstrukcja art. 234 Konstytucji stwarza pewne istotne wątpliwości. Pierwszą kwestią jest określenie podmiotu uprawnionego do stwierdzenia faktu niemożności zebrania się Sejmu na posiedzenie. Można w tej mierze wskazać trzy możliwe rozwiązania.

Pierwsze, sugerowane w literaturze przedmiotu ${ }^{17}$, przyjmuje, że uprawniony do tego jest Marszałek Sejmu. Znajduje to uzasadnienie w jego roli i pozycji nakreślonej w art. 110 Konstytucji. Marszałek izby, którego Konstytucja wyposaża w prawo kierowania pracami Sejmu i reprezentowania go na zewnętrz, ma wszelkie dane ku temu, by dokonać oceny sytuacji z punktu widzenia zdolności Sejmu do wykonywania funkcji ustawodawczej. Z drugiej jednakże strony w sytuacji nadzwyczajnej można dopuścić również możliwość, że Marszałek Sejmu na skutek okoliczności faktycznych nie będzie mógł poinformować organów władzy wykonawczej o zaistnieniu omawianej okoliczności.

Druga możliwość to przyznanie Radzie Ministrów prawa do oceny zdolności Sejmu do działania. Rada Ministrów w świetle art. 234 jest organem inicjującym procedurę wydania rozporządzenia z mocą ustawy. Bez przekonania Rady Ministrów o konieczności wydania aktu nie ma możliwości, by jakiekolwiek normy prawne w powyższej formie stały się prawem powszechnie obowiązującym. Można przyjąć, że w sytuacji gdy Rada Ministrów dostrzeże niezdolność Sejmu do działania, może złożyć stosowny wniosek na ręce Prezydenta RP.

Trzecie rozwiązanie zakłada przyznanie tego prawa Prezydentowi, który w zależności od własnej oceny sytuacji mógłby przychylić się do wniosku Rady Ministrów i wydać rozporządzenie bądź też uznać, że wniosek jest bezzasadny i odmówić jego wydania, z tym że przyjęcie tego punktu widzenia musiałoby się wiązać z przyznaniem Prezydentowi prawa do odmowy wydania rozporządzenia, co jest rozwiązaniem co do zasady kwestionowanym w literaturze przedmiotu ${ }^{18}$. Uznanie prawa Prezydenta do odmowy wydania

${ }^{16}$ K. Działocha, Komentarz do art. 234 Konstytucji, [w:] L. Garlicki (red.), Konstytucja Rzeczypospolitej Polskiej, t. IV, Warszawa 2005, s. 2; K. Prokop, O dopuszczalności..., s. 49; W. Skrzydło, dz. cyt., s. 277; P. Winczorek, Komentarz do Konstytucji Rzeczypospolitej Polskiej, Warszawa 2000, s. 300.

${ }^{17}$ K. Prokop, Stany nadzwyczajne..., s. 176.

${ }^{18}$ B. Banaszak, Konstytucja Rzeczypospolitej Polskiej, Warszawa 2009, s. 993; K. Działocha, Komentarz..., s. 2; K. Prokop, Stany nadzwyczajne..., s. 185. 
rozporządzenia z mocą ustawy wynika pośrednio z brzmienia innych postanowień Konstytucji zawartych w rozdziale XI. Artykuły 229 oraz 230 dają Prezydentowi możliwość nieprzychylenia się do wniosku Rady Ministrów w sprawie wprowadzenia stanu wojennego bądź wyjątkowego, gdyż w obu tych artykułach zostało użyte słowo „może”. Choć jak zauważono w literaturze, Prezydent „powinien uszanować wniosek Rady Ministrów, ponieważ to rząd, a nie prezydent jest uprawniony i zarazem zobowiązany do prowadzenia polityki państwa także w sytuacji stanu nadzwyczajnego i to rząd ponosi odpowiedzialność polityczną i konstytucyjną za realizację stosownego rozporządzenia prezydenta, także z uwagi na fakt kontrasygnowania go przez prezesa RM" ${ }^{\prime 1}$. Natomiast $\mathrm{w}$ art. 234 słowa tego nie ma.

$\mathrm{W}$ istocie rozwiązanie to wymagałoby $\mathrm{w}$ zasadzie zgodnego uznania przez oba organy władzy wykonawczej niezdolności do zebrania się posłów w stosownej liczbie, gdyż bez wniosku Rady Ministrów Prezydent nie znalazłby się w sytuacji umożliwiającej dokonanie mu powyższej oceny. Co więcej kontrolę nad tym posiadałby także Prezes Rady Ministrów w momencie udzielania kontrasygnaty.

Rozstrzygnięcie powyższego dylematu może mieć niebagatelne znaczenie, szczególnie w sytuacji, gdy między organami władzy ustawodawczej i wykonawczej wystąpi istotna różnica w ocenie zdolności Sejmu do działania. W warunkach stanu wojennego może mieć miejsce również taki przebieg wypadków, że Sejm na skutek rozmaitych okoliczności faktycznych może posiadać i tracić, po czym ponownie odzyskiwać zdolność odbywania posiedzeń przy zachowaniu kworum. W razie występowania takiej sytuacji wyobraźmy sobie, że Marszałek Sejmu informuje Radę Ministrów i prezydenta o niemożności zebrania się Sejmu na posiedzenie. Pod wpływem tej informacji Rada Ministrów kieruje wniosek do Prezydenta, po czym w tym samym czasie do miejsca obrad Sejmu dociera grupa posłów, dzięki czemu ich liczba na posiedzeniu przekracza stan 230, o czym Marszałek Sejmu informuje egzekutywę. Jeśli uznamy, że stanowisko Marszałka Sejmu jest wiążące dla organów władzy wykonawczej, Prezydent nie mógłby wydać rozporządzenia, mimo że wpłynął już do niego wniosek Rady Ministrów. Jak więc miałoby się do tego uznanie, że Prezydent nie może odmówić wydania rozporządzenia, o które wniosła Rada Ministrów, a w szczególności, że w momencie składania wniosku Sejm zdolności do uchwalania ustaw nie posiadał. Można wprawdzie w tej sytuacji uznać, że legitymacja Rady Ministrów do złożenia wniosku stała się bezzasadna, i tym samym wniosek przestał spełniać wymogi konstytucyjne i jako taki przestał być więc dla Prezydenta wią-

${ }^{19}$ A. Chorążewska, Prezydent jako czynnik równowagi. Arbitraż prezydencki, „Przegląd Sejmowy" 2005, nr 6, s. 74. 
żący. Jednakże w warunkach potencjalnego konfliktu zbrojnego (a nie można wykluczyć, że stan wojenny nie zostanie wprowadzony w związku z toczącymi się na terytorium Rzeczypospolitej Polskiej działaniami zbrojnymi) odzyskanie przez Sejm zdolności do działania może być krótkotrwałe. Występowanie tego stanu rzeczy w niewielkich odstępach czasowych może w praktyce prowadzić do kompletnego paraliżu tworzenia prawa czy to $\mathrm{w}$ formie ustaw, czy rozporządzeń z mocą ustawy. Tymczasem myśl przewodnia całej konstrukcji rozporządzenia z mocą ustawy w naszej Konstytucji jest podporządkowana jak się wydaje zachowaniu zdolności prawotwórczej państwa w nadzwyczajnych okolicznościach faktycznych.

Na prawo odmowy wydania rozporządzenia przez prezydenta można też spojrzeć z punktu widzenia art. 126 Konstytucji. Zgodnie z jego brzmieniem, Prezydent jest gwarantem ciągłości władzy państwowej, stoi na straży suwerenności i bezpieczeństwa państwa. Jeżeli Prezydent uzna, że wydanie rozporządzenia stoi w sprzeczności z zadaniami, jakie postawiła przed nim Konstytucja, może odmówić wydania rozporządzenia, tym bardziej że tego rodzaju interpretację postanowień Konstytucji można spotkać w odniesieniu do innych kompetencji Prezydenta zawartych w Konstytucji, a które językowo zostały w Konstytucji określone w podobny sposób jak w odniesieniu do normy z art. 234. Przykładem może być choćby kwestia ratyfikacji umów międzynarodowych czy mianowania sędziów ${ }^{20}$. Wprawdzie mianowanie sędziów jest prerogatywą Prezydenta, a nie aktem kontrasygnowanym, co istotnie wpływa na analizę tej kompetencji. Jednakże z punktu widzenia użytych w Konstytucji sformułowań można dostrzec podobieństwo tej kompetencji do innych kompetencji nominacyjnych Prezydenta wykonywanych za kontrasygnatą. A jak wskazano w literaturze, co potwierdza także praktyka, Prezydent może nie przychylić się do wniosku Rady Ministrów ${ }^{21}$. W szczególności gdy akceptacja wniosku wiązałaby się $\mathrm{z}$ naruszeniem prawa ${ }^{22}$. Taka sytuacja może mieć miejsce w przypadku, gdy po złożenia wniosku przez Radę Ministrów Sejm odzyskałby zdolność do zebrania się na posiedzenie w liczbie co najmniej 230 posłów.

Przyjęcie podobnego poglądu w przypadku rozporządzeń z mocą ustawy prowadzić może do konkluzji, że Prezydent miałby prawo odmówić wydania

${ }^{20}$ P. Sarnecki, Prezydent Rzeczypospolitej Polskiej. Komentarz do przepisów, Kraków 2000, s. 64; J. Sułkowski, Uprawnienia Prezydenta RP do powoływania sędziów, „Przegląd Sejmowy” 2008, nr 4, s. 52-55.

${ }^{21}$ J. Czajkowski, Zwierzchnictwo nad siłami zbrojnymi w świetle praktyki stosowania Konstytucji RP z 1997 r., [w:] M. Grzybowski (red.), System rządów Rzeczypospolitej Polskiej, założenia konstytucyjne a praktyka ustrojowa, Warszawa 2006, s. 67; J. Karp, P. Mikuli, Realizacja uprawnień nominacyjnych Prezydenta RP, [w:] M. Grzybowski (red.), System rządów Rzeczypospolitej Polskiej, założenia konstytucyjne a praktyka ustrojowa, Warszawa 2006, s. 104-107.

22 A. Frankiewicz, Kontrasygnata aktów urzędowych prezydenta RP, Kraków 2004, s. $119-121$. 
rozporządzenia mimo wniosku Rady Ministrów w dwóch przypadkach: po pierwsze gdy Prezydent uznałby, iż wydanie rozporządzenia stoi w sprzeczności z jego zadaniami zawartymi w art. 126 Konstytucji, po drugie zaś w sytuacji, gdy Prezydent uznałby, że Rada Ministrów złożyła wniosek mimo braku wyczerpania przesłanki z art. 234, czyli niezdolności Sejmu do zebrania się na posiedzenie bądź też gdyby w międzyczasie Sejm tę zdolność odzyskał.

Powyższe rozważania skłaniają do refleksji, że przyjęte w Konstytucji rozwiązanie w praktyce może nastręczać poważne trudności. Przyjmując, że główną rolą rozporządzeń z mocą ustawy jest możliwość szybkiego tworzenia prawa przez organy państwa oraz mając na uwadze fakt, że Konstytucja $\mathrm{w}$ istotnym stopniu ogranicza ich zakres przedmiotowy, roztropna wydaje się taka interpretacja Konstytucji, która przekaże organom władzy wykonawczej większą swobodę w korzystaniu z tej formy tworzenia prawa. Szczególnie że akty te muszą zostać przedstawione Sejmowi do zatwierdzenia na najbliższym posiedzeniu. Jeżeli Sejm uzna, że są one niepotrzebne lub zgoła szkodliwe bądź też wydane w sytuacji posiadania przez Sejm zdolności do stanowienia ustaw, może ich po prostu nie zatwierdzić. Najlepszym rozwiązaniem rzecz jasna byłaby nowelizacja art. 234, która te wątpliwości by rozwiała.

Kolejną kwestią budzącą wątpliwości w literaturze jest fakt niewymienienia w art. 234 niezdolności Senatu do działania, jako przesłanki umożliwiającej wydanie w czasie stanu wojennego rozporządzenia z mocą ustawy. Pominięcie Senatu w art. 234 jest wyraźnym mankamentem. Może bowiem zdarzyć się tak, że Sejm będzie mógł zebrać się na posiedzeniu, natomiast Senat nie będzie miał możliwości tego uczynić. Literalne rozumienie art. 234 wskazuje, że w przypadku niemożności dokończenia postępowania ustawodawczego na skutek niezdolności do zebrania się Senatu, Rada Ministrów nie może wystąpić z wnioskiem do Prezydenta o wydanie rozporządzenia, nie został bowiem spełniony wymóg niemożności zebrania się Sejmu na posiedzeniu. Jednakże konstrukcja instytucji rozporządzenia z mocą ustawy w obowiązującej Konstytucji wskazuje, że zostało ono pomyślane jako instrument umożliwiający stanowienie prawa w przypadku niezdolności do działania parlamentu w czasie sytuacji nadzwyczajnej, zatem logiczne wydaje się, że jednym z warunków wydania rozporządzenia z mocą ustawy powinna być niemożność zebrania się na posiedzenie jednej z dwu izb, jako że obie razem stanowią władzę ustawodawczą.

Część autorów jednoznacznie stwierdza, że brak możliwości zebrania kworum w Senacie, przy jednoczesnej zdolności Sejmu do uchwalania ustaw, uniemożliwia wydanie rozporządzenia z mocą ustawy ${ }^{23}$.

${ }^{23}$ B. Dzierżyński, dz. cyt., s. 83; K. Prokop, Stany nadzwyczajne..., s. 174-175. 
Jednakże w literaturze przedmiotu można spotkać również pogląd, iż w związku z tym, że zarówno Sejm, jak i Senat pełnią funkcje ustawodawcze, niezdolność Senatu do działania także uniemożliwia uchwalanie ustaw i tym samym należy uznać, że niezdolność izby wyższej do zebrania kworum jest przesłanką umożliwiającą wydawanie rozporządzeń z mocą ustawy ${ }^{24}$. Między powyższymi stanowiskami występuje oczywisty dysonans, którego nie sposób usunąć. Interpretacja art. 234, zmierzająca do uznania niemożności działania Senatu jako okoliczności uprawniającej do wydawania rozporządzeń z mocą ustawy, jest moim zdaniem zbyt daleko idąca, ze względu na wyraźną rozbieżność w stosunku do wyraźnego brzmienia przepisu Konstytucji.

Uchwalenie ustawy w trybie art. 121 ust. 2 Konstytucji jest dostępnym rozwiązaniem w omawianej sytuacji. Po uchwaleniu ustawy przez Sejm należałoby poczekać $30 \mathrm{dni}$, jakie Konstytucja przewiduje na zgłoszenie poprawek przez Senat i dopiero po bezskutecznym upływie terminu uznać, że Senat nie zgłosił weta do projektu. Uprawniałoby to Marszałka Sejmu do przekazania ustawy do podpisu Prezydentowi. Z punktu widzenia postanowień Konstytucji taka jej interpretacja także budzi kontrowersje w literaturze przedmiotu. Jeżeli nawet przyjmiemy, że proponowana interpretacja norm konstytucyjnych wydaje się poprawna, rozwiązanie to także jest wysoce niesatysfakcjonujące, a wręcz „nie do przyjęcia” z perspektywy celu wydawania rozporządzeń $\mathrm{z}$ mocą ustawy $\mathrm{w}$ warunkach stanu wojennego ${ }^{25}$. Warto bowiem jeszcze raz podkreślić, że konstrukcja rozporządzenia z mocą ustawy w obowiązującej Konstytucji kładzie punkt ciężkości na szybkie tworzenie prawa w nadzwyczajnych okolicznościach.

W literaturze proponowane jest rozwiązanie, by w tej sytuacji Marszałek Senatu przekazał niezwłocznie Marszałkowi Sejmu informacje o zaistniałym stanie rzeczy, co miałoby upoważniać tego ostatniego do przekazania ustawy do podpisu Prezydentowi, przyjmując założenie, że Senat nie wnosi poprawek $^{26}$. Rozwiązanie to budzi jednakże pewne wątpliwości. W literaturze zwraca się uwagę, że jest to wyraźna „nadinterpretacja art. 121 ust. 2 zdanie drugie i wyrwanie jej z całego kontekstu kompleksowej regulacji normalnego postępowania ustawodawczego" ${ }^{27}$. Jest to tym bardziej dyskusyjne w sytuacji, gdy w ciągu 30 dni, jakie Konstytucja przyznaje Senatowi na wyrażenie swojego stanowiska w stosunku do ustawy, Senat odzyska zdolność do działania, a przekazanie ustawy Prezydentowi do podpisu uniemożliwi Senatowi skorzystanie z jego konstytucyjnych uprawnień. Podpisanie w tym momencie ustawy przez Prezydenta byłoby jawnym pogwałceniem Konsty-

\footnotetext{
${ }^{24}$ B. Banaszak, dz. cyt., s. 991-992; W. Skrzydło, dz. cyt., s. 277.

${ }^{25}$ M. Nowakowski, dz. cyt., s. 58.

${ }^{26}$ K. Prokop, Stany nadzwyczajne..., s. 175.

${ }^{27}$ B. Banaszak, dz. cyt., s. 992.
} 
tucji. Ma to tym większe znaczenie, że w Senacie może posiadać większość ugrupowanie bądź ugrupowania, które w Sejmie znajdują się w opozycji. Trzeba pamiętać przy tym, że podobnie jak pisałem wcześniej w odniesieniu do Sejmu, Senat także w 30-dniowym terminie może na zmianę posiadać, tracić, po czym znowu odzyskiwać zdolność do działania.

Pominięcie Senatu w art. 234 Konstytucji jest moim zdaniem istotnym błędem prawodawcy konstytucyjnego. Warto bowiem zastanowić się nad ewentualnymi konsekwencjami przyjętej regulacji. Niezdolność Senatu do działania stawia pod znakiem zapytania dalsze postępowanie z projektem ustawy uchwalonej przez Sejm. Wydaje się, że żadne z zaproponowanych rozwiązań nie jest w pełni satysfakcjonujące. Sytuacja ta może przysporzyć licznych problemów faktycznych związanych z procesem ustawodawczym w czasie stanu wojennego, gdyż przepisy Konstytucji nie dają jasnej odpowiedzi na pytanie, jak powinien przebiegać ten proces w sytuacji niemożności działania Senatu.

Wydaje się, że biorąc pod uwagę efektywność instrumentu rozporządzenia z mocą ustawy w warunkach stanu wojennego, także w tej mierze pożądana byłaby zmiana konstytucji, która polegałaby na dopisaniu do artykułu 234 Konstytucji dodatkowej przesłanki uprawniającej do wydawania tych aktów w postaci niemożności zebrania się na posiedzeniu Sejmu lub Senatu.

Trzecią przesłanką, której wystąpienie jest konieczne do wydania rozporządzenia z mocą ustawy, jest złożenie wniosku przez Radę Ministrów. Stanowi to poważne ograniczenie w swobodzie wydawania tego rodzaju rozporządzeń przez Prezydenta. W doktrynie panuje zgoda, że w praktyce projekt rozporządzenia stworzony zostanie przez Radę Ministrów, która składając wniosek o wydanie rozporządzenia, powinna dołączyć do niego projekt aktu wraz z uzasadnieniem ${ }^{28}$. Rodzi się natomiast wątpliwość, czy Prezydent, wydając rozporządzenie, jest związany zakresem przedmiotowym i treścią projektu rozporządzenia.

W tym miejscu powraca kwestia ewentualnego prawa Prezydenta do odmowy wydania rozporządzenia. Warto zastanowić się nad rolą Prezydenta w tym procesie. Jeżeli uznamy, że Prezydent jest jedynie „notariuszem” decyzji Rady Ministrów i nie posiada żadnego wpływu na powstanie aktu, to rodzi się pytanie, do czego potrzebny byłby jego udział w tym postępowaniu. Tym bardziej że cel w postaci szybkości tworzenia prawa w warunkach nadzwyczajnych nakazuje maksymalne uproszczenie zasad tworzenia prawa. Gdyby uznać, że Prezydent nie może zająć żadnego stanowiska w stosunku do wniosku Rady Mi-

${ }^{28}$ B. Banaszak, dz. cyt., s. 992; M. Brzeziński, Stany nadzwyczajne w polskich konstytucjach, Warszawa 2007, s. 197; K. Prokop, Stany nadzwyczajne..., s. 182-183; P. Winczorek, Komentarz do konstytucji RP z dnia 2 IV 1997 roku, Warszawa 2000, s. 300; W. J. Wołpiuk, Państwo wobec szczególnych zagrożeń, Warszawa 2002, s. 107. 
nistrów i pozostaje mu je jedynie podpisać, to rozsądniej byłoby powierzyć wydawanie tych aktów wyłącznie Radzie Ministrów. Jeżeli przyjmiemy natomiast, jak proponowałem powyżej, że Prezydent ma prawo odmowy wydania rozporządzenia, to tym samym należy uznać, że posiada również kompetencje do modyfikacji jego treści. Rozwiązanie to nie prowadzi jednocześnie do pozbawienia rządu wpływu na ostateczny kształt aktu, gdyż konieczność udzielenia kontrasygnaty pod aktem przez Prezesa Rady Ministrów sprawia, że Prezydent zostaje poddany kontroli premiera. Tak interpretacja konstytucji oznacza konieczność współdziałania obu organów władzy wykonawczej w procesie tworzenia tej formy aktów prawnych. Tryb wyboru Prezydenta i zasady powoływania Rady Ministrów powodują, że wysoce prawdopodobna jest możliwość, iż oba te organy reprezentować będą różne opcje polityczne; tym samym może to utrudniać zawarcie kompromisu koniecznego do powstania danego aktu prawnego, lecz równocześnie stanowi pewnego rodzaju gwarancję, że akty te nie będą przez egzekutywę niewłaściwe wykorzystywane.

Odrębną kwestią jest sygnalizowany w literaturze problem ewentualnego obowiązku kontrasygnowania przez Prezesa Rady Ministrów aktu urzędowego Prezydenta odmawiającego wydania rozporządzenia z mocą usta$w^{29}$. Stojąc na stanowisku bezwzględnego obowiązku wydania przez Prezydenta rozporządzenia w przypadku złożenia wniosku przez Radę Ministrów, odmowa wydania aktu musiałaby się wiązać ze zmianą stanowiska Rady Ministrów co do celowości jego wydania. W innym przypadku Prezydent odmawiając wydania rozporządzenia popełniłby delikt konstytucyjny. Jeżeli jednak Rada Ministrów nie chciałaby wydania aktu, mogłaby cofnąć wniosek bądź skłonić prezydenta do wydania aktu urzędowego, którego treścią byłaby odmowa wydania rozporządzenia. Akt ten musiałby być wtedy kontrasygnowany przez Prezesa Rady Ministrów. Wydaje się jednak, że konstrukcja nakazująca kontrasygnowanie przez Prezesa Rady Ministrów odmowy wydania rozporządzenia jest dość karkołomna i nie znajduje dostatecznego uzasadnienia w utrwalonych poglądach doktryny na temat kontrasygnowania aktów urzędowych Prezydenta. W polskiej literaturze dominuje pogląd, że kontrasygnata dotyczyć może wyłącznie aktów w formie dokumentów pisanych $^{30}$. Wszelkie inne czynności podejmowane przez Prezydenta, które nie posiadają formy pisemnej, kontrasygnaty nie wymagają ${ }^{31}$. Nie ma w istocie

${ }^{29}$ K. Prokop, Stany nadzwyczajne.... , s. 185-187.

${ }^{30}$ A. Frankiewicz, dz. cyt., s. 87; S. Patyra, Prawnoustrojowy status Prezesa Rady Ministrów w świetle konstytucji z 2 kwietnia 1997 r., Warszawa 2002, s. 136; P. Sarnecki, Komentarz do art. 144 ust. 2, [w:] L. Garlicki (red.), Konstytucja Rzeczypospolitej Polskiej, t. I, Warszawa 1999, s. 2.

${ }^{31}$ A. Rakowska, Kontrasygnata aktów głowy państwa $w$ wybranych państwach europejskich, Toruń 2009, s. 218. 
sposobu na zmuszenie Prezydenta do wydania aktu urzędowego, w którym Prezydent odmawia wykonania konstytucyjnego uprawnienia.

Rozstrzygnięcie powyższego problemu sprowadza się więc do odpowiedzi na pytanie, czy Prezydent może czy nie może odmówić wydania rozporządzenia, o które wnosi Rada Ministrów. Jeżeli przyjmiemy, że Prezydentowi przysługuje takie uprawnienie, trudno wymagać od Prezesa Rady Ministrów, by kontrasygnował akt, za który ponosi odpowiedzialność polityczną przed Sejmem, nie mając wpływu na decyzję Prezydenta. Jeżeli natomiast odmawiamy tego prawa Prezydentowi, wymóg kontrasygnowania aktu zawierającego decyzję odmowną jest bez sensu, gdyż bez względu na jej udzielenie lub nieudzielenie, Prezydent i tak popełnia delikt konstytucyjny rodzący możliwość postawienia go przed Trybunałem Stanu. Obowiązek kontrasygnowania takiego aktu przez premiera prowadziłby dodatkowo do możliwości egzekwowania wobec niego odpowiedzialności politycznej, i miałby sens jedynie wtedy, gdy Prezes Rady Ministrów aprobowałby podjęcie takiej decyzji przez Prezydenta.

Rozporządzenia z mocą ustawy wydawane są w zakresie i granicach określonych w art. 228 ust. 3-5 Konstytucji. Oznacza to nałożenie na rozporządzenia - w czasie trwania stanu nadzwyczajnego - tych samych ograniczeń co na ustawy, a więc konieczność respektowania zasad legalności, proporcjonalności i celowości. Działania podejmowane w wyniku wprowadzenia stanu nadzwyczajnego powinny respektować zasadę proporcjonalności, tzn. muszą odpowiadać stopniowi występującego zagrożenia (art. 228 ust. 5). Użycie nadmiernych środków, niewspółmiernych do zaistniałej sytuacji, będzie więc działaniem nieusprawiedliwionym nawet w czasie stanu nadzwyczajnego. Powinny także zmierzać do jak najszybszego przywrócenia normalnego funkcjonowania państwa (art. 228 ust. 5). Oznacza to, iż prawodawca konstytucyjny podkreśla w ten sposób tymczasowy charakter stanów nadzwyczajnych. W czasie stanu nadzwyczajnego nie mogą być zmienione: Konstytucja, ordynacje wyborcze do Sejmu i Senatu oraz organów samorządu terytorialnego, ustawa o wyborze Prezydenta Rzeczypospolitej oraz ustawy o stanach nadzwyczajnych. Ograniczenie to dotyczy także rozporządzeń z mocą ustawy, przez co Konstytucja w istotnym stopniu zawęziła przedmiot ich regulacji, gdyż materia rozporządzenia może obejmować wyłącznie sprawy nieuregulowane $\mathrm{w}$ ustawie o stanie wojennym ${ }^{32}$. Jak trafnie dostrzeżono $\mathrm{w}$ literaturze, Konstytucja „dopuszcza tylko rozporządzenia z mocy ustawy praeter legem w zakresie działań podejmowanych w wyniku wprowadzenia stanu wojennego, gdy wcześniejsze regulacje zawarte w ustawie o stanie wojennym okazały się niepełne i w tym sensie niewystarczające dla zwalczenia jego przyczyn"33.

\footnotetext{
${ }^{32}$ B. Dzierżynski, dz. cyt., s. 88.

${ }^{33}$ K. Działocha, Komentarz..., s. 3.
} 
Wydane przez Prezydenta rozporządzenia z mocą ustawy są źródłem powszechnie obowiązującego prawa. Nie mają jednak charakteru ostatecznego. Podlegają bowiem zatwierdzeniu przez Sejm na najbliższym posiedzeniu, tzn. pierwszym, które może się odbyć po ich wydaniu. Zatwierdzenie to powinno nastąpić $\mathrm{w}$ formie uchwały. Warto podkreślić, że w procesie zatwierdzania rozporządzeń nie bierze udziału Senat, co nakazuje przyjąć, iż uprawnienie to zalicza się do funkcji kontrolnej, którą sprawuje samodzielnie izba niższa, a nie do funkcji ustawodawczej, w której biorą udział obie izby. Artykuł 234 Konstytucji nie rozstrzyga, w którym momencie następuje utrata mocy obowiązującej, jeśli Sejm nie zatwierdzi rozporządzenia. Praktyczne podejście do tego problemu nakazuje wszak uznać, że utrata mocy obowiązującej przez dany akt następuje od momentu odmowy zatwierdzenia aktu (ex nunc). Przyjęcie odmiennej interpretacji, czyli uznanie, iż akt jest nieważny od początku (ex tunc), mogłoby prowadzić do licznych kontrowersji prawnych i praktycznych, szczególnie w razie dłuższego obowiązywania rozporządzenia. Bez względu na rodzaj decyzji podjętej przez Sejm w stosunku do aktu do tego momentu rozporządzenie jest źródłem prawa powszechnie obowiązującego.

Kontrolę nad rozporządzeniami z mocą ustawy oprócz Sejmu sprawuje także Trybunał Konstytucyjny w trybie wynikającym z art. 188 pkt 3 Konstytucji, który przyznaje Trybunałowi prawo badania zgodności przepisów prawa, wydawanych przez centralne organy państwowe, z Konstytucją, ratyfikowanymi umowami międzynarodowymi i ustawami. Postanowienia Konstytucji nie są jednak w tej mierze jednoznaczne i nie dają jasnej odpowiedzi, czy Trybunał może sprawować w stosunku do rozporządzeń kontrolę przed ich zatwierdzeniem przez Sejm, czy też dopiero po dokonaniu tej czynności. Z całą pewnością natomiast musi być to kontrola następcza. W literaturze zwrócono uwagę, że lepszym rozwiązaniem jest uznanie, że kontrola Trybunału powinna mieć miejsce po przedłożeniu rozporządzenia Sejmowi do zatwierdzenia. Miałyby za tym przemawiać następujące argumenty. Po pierwsze, w czasie stanu wojennego może mieć miejsce paraliż działania organów państwa, również tych, które posiadają prawo wnoszenia wniosku do Trybunału o kontrolę konstytucyjności prawa. Mogłoby to dodatkowo „opóźniać i komplikować ich wejście w życie” ${ }^{34}$. Po drugie, kontrola rozporządzeń przez Trybunał przed ich przedłożeniem Sejmowi do zatwierdzenia mogłaby być bezprzedmiotowa w sytuacji, gdyby Sejm ich nie zatwierdził ${ }^{35}$. Choć są to trafne spostrzeżenia, to posiadają jeden mankament, nie biorą bowiem pod uwagę, że w warunkach stanu wojennego trudno przewidzieć,

\footnotetext{
${ }^{34}$ B. Dzierżynski, dz. cyt., s. 90.

${ }^{35}$ Tamże.
} 
kiedy Sejm odzyska zdolność do działania. Tym samym moment, w którym Sejm będzie mógł przystąpić do rozpatrzenia tej kwestii, może być odległy w czasie. Natomiast choćby ze względu na mniejszy liczebnie skład Trybunału niż Sejmu może on w warunkach wojennych posiadać zdolność do realizacji swoich konstytucyjnych obowiązków. Ze względu na brak przeszkód konstytucyjnych w sprawowaniu swoich zadań przez Trybunał, należy uznać, że może on dokonać kontroli konstytucyjności rozporządzenia z mocą ustawy w dowolnym momencie po jego wejściu w życie, rzecz jasna na wniosek podmiotu uprawnionego do tego przez art. 191 Konstytucji.

Przeprowadzone rozważania prowadzą do wniosku, że konstrukcja art. 234 Konstytucji posiada istotne mankamenty, które nastręczają rozmaitych wątpliwości interpretacyjnych. Wydaje się, że z tego względu jego nowelizacja jest konieczna. Szczególnie że odmienne stanowiska doktryny w stosunku do wykładni przepisu mogą stwarzać pole do poważnych konfliktów politycznych związanych ze stosowaniem tej instytucji. Z pozoru można ten problem uznać za nieistotny ze względu na incydentalny charakter tej formy aktu normatywnego. Jednakże jak uczy doświadczenie innych państw, w warunkach kryzysu państwa spowodowanego wojną lub niebezpieczeństwem jej wystąpienia, praktyka stosowania norm konstytucyjnych, przy braku ich precyzji oraz konkretyzacji postanowień konstytucji przez akty normatywne niższego rzędu, może doprowadzić nie tylko do konfliktów politycznych, lecz także do wykształcenia praktyki stosowania normy konstytucyjnej całkowicie sprzecznej z jej treścią i w zgodnej ocenie doktryny niezgodnej ze standardami demokratycznego państwa prawa ${ }^{36}$.

${ }^{36}$ Doskonałym przykładem takiej praktyki było wydawanie rozporządzeń z mocą ustawy przez Prezydenta Republiki Chorwacji w latach 1990-1995 r. Szerzej na ten temat zob.: K. Składowski, System rządów w Republice Chorwacji, Łódź 2013, s. 352-354. 